\title{
Determinants of Entrepreneurial Intention
}

\section{among African Students in China}

\author{
Prof. Wang Jinying ${ }^{1} \&$ Pene Zongabiro Nina Pelagie ${ }^{2}$ \\ ${ }^{1}$ Professor of College of Economics, Hebei University, Baoding, China \\ ${ }^{2} \mathrm{PhD}$ student of College of Economics, Hebei University, Baoding, China \\ Correspondence: Pene Zongabiro Nina Pelagie, Hebei University, Baoding, China. E-mail: penenina@yahoo.fr
}

Received: September 29, 2014

Accepted: October 20, 2014

Online Published: October 22, 2014

doi:10.5430/ijhe.v3n4p106

URL: http://dx.doi.org/10.5430/ijhe.v3n4p106

\begin{abstract}
Students' perceptions towards entrepreneurship have been a focus for many researches in the field of Entrepreneurship: Given the role that entrepreneurship play in the economic development of a country, researchers acknowledge that students are the key population for entrepreneurial activities. Researchers want to predict and understand students' attitudes towards entrepreneurship through various studies largely based on: socio demographic characters, entrepreneurship training program, social background and motivation for the students regarding job choice. The study aims to find out the determinants of entrepreneurial intention among African students studying various disciplines in China base on the theory of planned behavior. The entrepreneurial intention model was tested and its verified hypothesis and descriptive statistics was used for empirical analysis. The study was conducted through a survey on 148 students and the results revealed the Africa economic environment, gender and fields of study are main determinants of African students' entrepreneurial intention. These results revealed the importance of African students' training in the fields of economics and engineering sciences to develop their entrepreneurial spirit and the need for African governments to create a suitable economic environment to further stimulate the entrepreneurial spirit of these students when they return to Africa.
\end{abstract}

Keywords: Entrepreneurship, Entrepreneurial intention, Intention model, Economic environment

\section{Introduction}

The Chinese economic development which is being acknowledged worldwide is as a result of the 1978 economic reform. The economic reform promoted the development of private enterprises, but private sector achieved its important development under Deng's theory in 1992 where both central and local Governments encouraged private investments, individual business and foreign investments (Liu, 2002). In 2010, China became the world's second largest economy due to its continuous progressive economic policies.

Chow (2004) indicates that China's economic and social reforms also impacted the Chinese system of education. The author postulates that because of the admired quality of Chinese education system, foreign lecturers and students from Africa come to China for work and studies and the number of foreign students wanting to study in China has been on the increase.

Wei (2012) clarifies that with its economic development; China is admitting more and more international students in many of its universities. Currently, China has around 1,000 Colleges and universities. Wei (2012) confirms that Chinese government offers scholarships to foreign or international students studying in China increases rapidly. Some universities, such as Beijing University and Tsinghua University, have already gained international reputation for their outstanding teaching and research facilities. Chinese universities now offer degrees in English thereby enabling students from English speaking countries to study in China without a requirement of learning Chinese language. Students from Africa are gradually increasing in number in institutions of higher learning in China and are gaining experience in various academic domains (Note 1). Students from Africa have manifested entrepreneurship aspiration because they have witnessed the linkages between production, teaching and research in China, having realized that China's schools of higher learning speed up the processes in turning science-technology research results into production, giving rise to many new and higher technology enterprises and important innovations. 
Scholars' analysis and approaches in the field of entrepreneurship generally following three main perspectives. The first perspectives focused on individual personal characteristics such as personal beliefs (Boissin, Chollet \& Emin, 2008), needs of achievement (McClellan, 1961) and self-capability Bandura (1997) in stimulating individuals' intention to undertake entrepreneurship acts. The second perspective focus on entrepreneurs' social environment; on the impact of social networks; mainly social groups (parents, friends, etc) in encouraging entrepreneurial activities by providing resources to entrepreneurs (Shapero \& Sokol, 1982 and Robinson, Stimpson, Huefner \& Hunt, 1991). The third perspective focused on the role of institutions (politic, economic and legal structures) in shaping individual intention regarding economic activities and providing facilities and a suitable environment to the development of economics activities (Acemoglu, Johnson, Robinson \& Thaicharoen, 2003).

This current paper studying entrepreneurial intention of African students is in respect to these three perspectives but mainly focused on personal characteristics and the role of institutions as stimulus to entrepreneurship. This research contributes to the current debates on the roles of social norms and institutions and its influences on economics activities in emerging and developing countries (Djankov, Qian, Roland \& Zhuravskaya, 2006, Bruton, Ahstrom \& Obloj, 2008 Black \& Castaldo, 2009 and De Clercq, Danis \& Dakhili, 2010). Scholars used students as a target population in studying entrepreneurship in most emerging countries (Gupta et al., 2014). Therefore, the aim of this study is to find out, through analysis, determinants leading African students' aspiration towards entrepreneurship in China and followed by the research question: What could be the impact of the change of educational system and economic environment on entrepreneurial intention of African students studying in China? To answer this question, the study focused on the African students who were at the end of their studies in China. Analysis mainly based on students' personal characteristics (age, gender, study level, fields of study) and environment context (home country and city location in China) based on the theory of planned behavior, and then logistic regression model was drawn to test the variables of personal characteristics and institutional environment, in doing so, the paper make two main contributions. First the paper stressed that individual personal beliefs and self- capability have the influence on the individual decision to become an entrepreneur (Boissin et al., 2008 and Zhao, Seibert \& Hills, 2005). Second, a country's favorable institutional environment influence positively individuals' intention towards entrepreneurship activities (Djankov et al., 2006 and Bruton et al., 2008).

This paper is organized as follows: literature review, objectives and hypothesis, methodology of the study, findings and interpretations, discussion and conclusion, and limitations and directions for future research.

\section{Literature review}

\subsection{Entrepreneurship and Economic Development}

Researchers in entrepreneurship domain broadly focus on entrepreneur's personal traits mainly in the fields of psychology and sociology (McClellan, 1961) while in management and economics researchers are interested in entrepreneur's acts (Stevenson \& Jarillo, 1990) and the role of entrepreneur in economic development (Drucker, 1985).

Since each research domain has its own perspective, it is difficult to find a single definition of entrepreneurship, researchers consider an entrepreneur as someone who stimulates economic growth and economic development through innovation (Schumpeter, 1939) or using opportunities to create goods and services (Shane \& Venkataraman, 2000). On the other hand, some authors consider entrepreneurship as a phenomenon that leads to enterprise creation impulse by an individual or by a group of individuals (Verstraete, 2003) while other defined entrepreneurship as dynamic process in which value is created by an entrepreneur who used various resources to create this value (Ronstadt, 1984). To meet Verstraete (2003) and Ronstadt (1984) we can confirm that an entrepreneur is someone who perceived an opportunity and used the innovation to create a new value within an enterprise.

Institutions appear to play a key role in the development of economics activities as well as the development of entrepreneurship in many countries. North (1990) argued that institutions both formal (government laws, policies, rules and regulations) and informal (codes of conduct, norms and conventions in societies) provide incentives as well as constraints to economic development. Then Scott (2001) asserted that institutions are social structures that constrain individual behaviors. He argued that institutions provide stability and meaning to social life. Concerning the role of institutions in shaping the landscape of entrepreneurial activities, Casson (1990) asserted that the development of infrastructures improves the development of entrepreneurial activities. Then Kostova (1997) argued; Country Institutional Profile (CIP) namely regulatory dimension (government policies), cognitive dimension (social norms) and a normative institution (social values) explain the differences in the development of entrepreneurial activities across countries. While Acemoglu et al., (2003) asserted; some institutional environment influence positively economics activities and contribute to economic development while other constitute a constraint. Eesly 
(2009) asserted that institutional changes encourage lower human capital to undertake entrepreneurial activity due to response to lower entry constraint in entrepreneurship.

The favorable institutional environment which contributed to the economic development of most developed countries such as USA, Japan and New Zealand is attributed to the development of entrepreneurship (Williamson, 2000 and Campbell, 2004). Recently, the change in institutional environment of emerging countries such as, Russia and China that moved from central planned economy to market economy increased the development of entrepreneurial activities and contributes to economic growth of these countries (Bruton et al., 2008 and Gupta et al., 2014). Chow (2004) supports that China economic growth is explained from its economic reform which started in 1978, but the importance of Chinese economic reforms took place from the 1990s, when, the State gave-up more of its share in small and medium size enterprises. Then Li, Meng, and Zhang (2006) assert that this fact allowed the development of Chinese private sector, that from 1978 to 2001, China's private business produced more than one-third of China's industrial output. The economic observers recognized that a part of China's economic growth is attributed to the creation and the development of Chinese companies at both national level and international level. Liu (2002) also supports that private sector is a main component of Chinese economic growth. The unprecedented development of China's economic growth is admired by economic analysts and students as well.

African students having acquired degrees and technical skills and having lived in Chinese economic environment with a lot of small businesses around their universities, manifest the enterprise spirit in the sense that they wish to create their own companies or generating income activities after their return to Africa. However, African students in China have various perception of the notion of entrepreneurship, some of them related entrepreneurship notion to a creation notion (creation of company, creation of value of wealth and creation of generating income activities, while others link entrepreneurship to business opportunity and innovation. African students' perception of entrepreneurship reveals the fact that entrepreneurial spirit is not limited to enterprise creation, as supported by Drucker (1985) who stipulates that entrepreneurship is not only limited to economic units. So, African students believe that entrepreneurial spirit could be perceived as the willingness to take initiatives and to organize activities and available resources to achieve the desired results (goods and services) whatever the field of activity (e.g. economic, social, political, etc.).

\subsection{Application of the Theory of planned behavior to African students' intentions on entrepreneurship}

Ajzen and Fishbein (2000: 13) affirm that "attitude could explain human behavior". These authors developed the theory of planned behavior to explain human behavior. Many studies like those ones of Schifter and Ajzen (1985) and Nguyen, Potvin, and Otis (1997) used the theory of reasoned action or theory of planned behavior in various domains such as health and education to predict and understand healthy behavior. They were also used in the fields of management and economics sciences to analyze student's intention toward entrepreneurship; as it is witnessed by Boissin, Chollet, and Emin (2008) and Zhao, Seibert, and. Hills (2005). This can also be used to predict customer's behavior towards new products, as recognized by Kurland (1996) and Ajzen (2008).

Researchers in the field of entrepreneurship apply the Theory of Planned Behavior (Ajzen, 1991) as well as Entrepreneurial Event Model developed by Shapero, and Sokol (1982) to predict and understand individual behavior towards entrepreneurship. Boissin et al. (2008) recognized that those models are necessary to predict and understand students' intention towards entrepreneurship and they applied theory of planned behavior to students' intention towards enterprise creation. Then they concluded the intention to create enterprise is higher when enterprise creation is perceived as a desirable and feasible action. Tounes (2006) in his research analyzed the impact of entrepreneurship training on student's intention towards entrepreneurship and he defined intention as a will of an individual enrolled in a cognitive process conditioned by the socio-cultural, political and economic context. Zhao et al. (2005) analyzed the role of self-efficacy on entrepreneurial intentions and behavior, they found that individual choose to become an entrepreneur most directly because they are high in self-efficacy and they believe they can succeed in this role. Liñan (2004) studied the effect of training programme on entrepreneurship on students' entrepreneurial intention also found that training programme have a positive impact on student's perception towards entrepreneurship.

According to Ajzen (1991: 181), intention precedes the behavior. The author indicates; in general the stronger the intention to engage in a behavior, the more likely should be its performance. The theory of planned behavior postulates that the intention to perform the behavior is influenced by three independent components such as attitude, subjective norms and perceived behavioral control.

An attitude is an individual positive or negative belief to perform a behavior. Subjective norms refer to perceived social pressure (family or friends opinions) to perform or not the behavior. Perceived behavioral control refers to ease or difficulty of performing the behavior. Perceived behavioral control assumes to reflect past experiences and 
resources or opportunities under control as well as obstacles. Attitudes are assumed to have a direct effect on behavioral intention and are linked with subjective norms and perceived behavioral control (Ajzen, 1991).

African students' intentions toward entrepreneurship (be an entrepreneur) are as well influenced by three components of intentions; these are attitudes measured from their personal traits (age, gender, study level and fields of study) that influence the students beliefs (Boissin et al., 2008). Their motivations for career choice, subjective norms usually referred to groups of people (friends, parents). But in this study, the environment context was chosen (Student home country and location in China). Their behavior meets the research theory of Bandura (1997) revealing that subjective norms and perceived behavioral control are measured from personal capability or Self-efficacy to create enterprise (personal factor). So, the probability for Africans students to become entrepreneurs or to create enterprise will depend on: a) The attitudes they have towards enterprise creation; b) The opportunities perceived from their environment and c) Their personal capability (self-efficacy). Therefore, the theory of planned behavior applies to African students intentions can be modeled as follow:

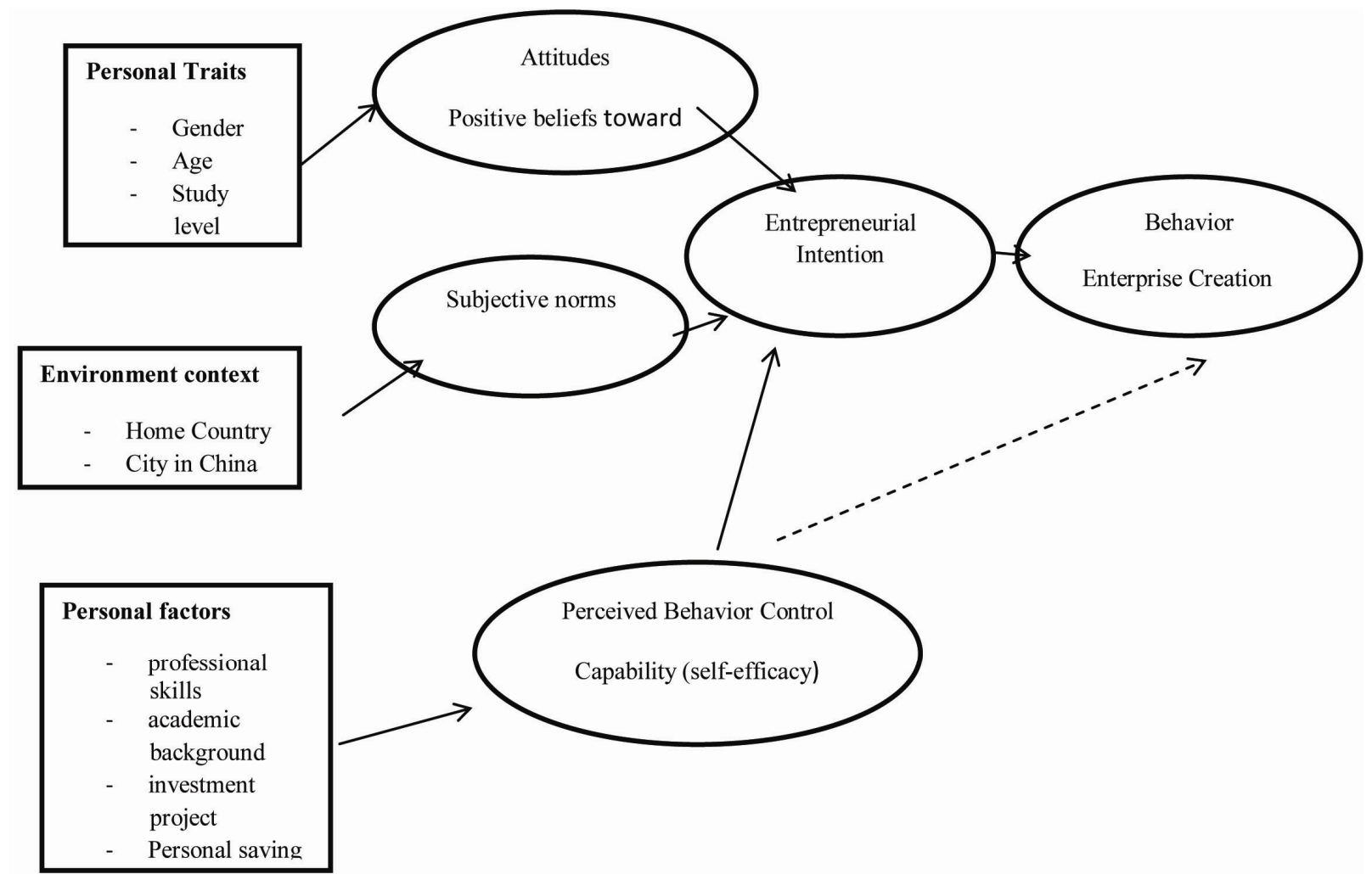

Figure 1. The Theory of Planned Behavior apply to African students' entrepreneurial Intention (Note 2)

\section{Objective and hypothesis of the study}

As earlier noticed in the literature review, student's intentions toward entrepreneurship have been studied by several authors. The majority of researches on students' intentions focus on the impact of students training or entrepreneurship programme on student's perception towards entrepreneurship (Tounes 2006; Zhao et al. 2005; Boissin et al. 2008, and Liñán 2004). Also none or few researches have been conducted on the entrepreneurial intention of African students outside Africa. Thus this research analyses the determinants of African students' intention towards entrepreneurship in a foreign country. So the main objective of this study is to prove that some determinants such as personal background and the change of environment influences students' intention towards entrepreneurship. China with a lot of developmental business activities is a place of learning entrepreneurship spirit or enterprise creation. In another words, China's economic environment stimulate African students enterprise spirit, such that after graduation they will start their own business activities and create enterprises necessary for economic development of Africa.

In this study, we have formulated the three following hypotheses:

Hypothesis 1: African students' attitudes are determinant factors that influence positively their entrepreneurial intention. 
Hypothesis 2: African students' institutional environment is determinant factor of entrepreneurial intention.

Hypothesis 3: The perceived African students' capability (personal factors) positively influences their entrepreneurial intention.

\section{Methodology of the study}

\subsection{Data collection}

The survey was carried out among African students from different parts of Africa (North, South, East, West and Central) living and studying in china. The choice of respondent was guided by the criteria of the graduation year and the return to Africa, where they will face professional career choices. So, we focused particularly on students who were at the end of their studies in China; this means that those who will be graduating one year or two years later from the date of survey. The data were collected from January to February 2014. The Survey sample was 148 Students from 20 cities (122 respondents from the North part and 26 from South) in China, and from more than 25 Universities. All study levels were included (Bachelors (39.9\%), Masters (49.3\%) and Doctorates (6.1\%). The average age of respondents is 26.60 years (Minimum 17 years and maximum 45 years). According to gender distribution, 88 respondents are male and 60 respondents are female. The question student profile contained the age, gender, academic level, fields of study, Africa origin and location in China), and questions were related on their perception of entrepreneurship notion, motivation of career choices (attitudes), the environment that influence their career choices (subjective norms) and the personal factors that influence enterprise creation (perceived behavior control). Sample characteristics is summarize in table 1.

Table 1. Sample Characteristics

\begin{tabular}{|c|c|c|c|}
\hline Variables & & Respondents & Percentage \\
\hline \multirow[t]{2}{*}{ Gender } & Male & 88 & 59.5 \\
\hline & Female & 60 & 40.5 \\
\hline \multirow[t]{3}{*}{ Age } & Minimum & 17 & \\
\hline & Maximum & 45 & \\
\hline & Average & 26.60 & \\
\hline \multirow[t]{4}{*}{ Study Level } & Bachelors & 59 & 39.9 \\
\hline & Master & 73 & 49.3 \\
\hline & Doctorate & 9 & 6.1 \\
\hline & Others level & 7 & 4.7 \\
\hline \multirow[t]{5}{*}{ Africa Origin } & North of Africa & 5 & 3.4 \\
\hline & West of Africa & 49 & 33.1 \\
\hline & Central of Africa & 37 & 25.0 \\
\hline & East of Africa & 31 & 20.9 \\
\hline & Southern Africa & 26 & 17.6 \\
\hline \multirow[t]{4}{*}{ Fields of study (Specialty) } & Medicine & 55 & 37.2 \\
\hline & Engineering & 34 & 23.0 \\
\hline & Economics & 15 & 10.1 \\
\hline & Others major & 44 & 29.7 \\
\hline \multirow[t]{2}{*}{ Location in China(City) } & $\begin{array}{l}\text { North of China } \\
\text { (13 cities) }\end{array}$ & 122 & 82.43 \\
\hline & $\begin{array}{l}\text { South of China } \\
\text { ( } 07 \text { cities) }\end{array}$ & 26 & 17.57 \\
\hline
\end{tabular}

Source: Authors' survey 


\subsection{Data Analysis}

The questions were administered directly to sample on paper support and the large part was done through mail. Counting proceeded, after this step, out of 153 questions, 5 of them were not treated and were rejected; 148 questions were treated using statistical software. Census and Survey Processing System (CSPRO 4.1) for data entry, Statistical Package for Social Science (SPSS17) for descriptive statistics and Statistics Data Analysis (STATA 11) for modeling.

The Ajzen (1991) theory of planned behavior model was the theory that sustained the study. The dependent variable was entrepreneurial intention and independents variables were attitudes towards entrepreneurship, environment context and capability perceived. Dichotomy answers (Yes or No) were used as measurement of each item. Attitudes and environment context was analyzed using logistic regression model while capability perceived was analyzed through descriptive statistics.

This study, refined the estimation of the determinants variable to the choice of being an entrepreneur. Given the dichotomous nature of the dependent variable (being an entrepreneur or not), the logistic model was indicated in such study (Hosmer, Lemeshow \& Sturdivant, 2000). In logistic regression model, the expected value of Y is conditional to X, but in this case the relationship was not linear, so the residues cannot be normally distributed. The dependent variable was qualitative with two values ( 1 if being an entrepreneur or 0 if not). The model evaluated the link between the expected value of dependent variable $(\mathrm{Y})$ and the vector of independent variable $(\mathrm{X})$ : that is the regression of $\mathrm{Y}$ on $\mathrm{X}$, see Equation (1):

$$
\mathrm{E}(\mathrm{Y}=1 \mid \mathrm{X})=\sum_{\mathrm{Y}} \mathrm{P}(\mathrm{Y}) \mathrm{Y}=\mathrm{P}(\mathrm{Y}=1) * 1+\mathrm{P}(\mathrm{Y}=0) * 0=\mathrm{F}(\beta \mathrm{X})=\beta_{0}+\beta_{1} \mathrm{X}_{1}+\cdots+\beta_{\mathrm{k}} \mathrm{X}_{\mathrm{k}}
$$

Thus, the probability that a respondent become an entrepreneur: $\left(\operatorname{Pr}\left(y_{i}=1 \mid X_{i}\right)\right)$ depend on a set of explanatory variables $\left(X_{i}\right)$. In fact the model explained the probability of becoming an entrepreneur: $\mathrm{P}(\mathrm{Y}=\mathrm{y} \mid \mathrm{X}) \in[0 ; 1]$. The measurements of each variable on probability it proceed by calculating the odds ratio, see Equation (2):

$$
\text { Odds ratio }=\frac{\operatorname{Pr}\left(y_{i}=1 \mid X_{i}\right)}{1-\operatorname{Pr}\left(y_{i}=1 \mid X_{i}\right)}=e^{\beta X_{i}} \Leftrightarrow \ln \left(\frac{\operatorname{Pr}\left(y_{i}=1 \mid X_{i}\right)}{1-\operatorname{Pr}\left(y_{i}=1 \mid X_{i}\right)}\right)=\beta_{0}+\beta_{i} X_{i}+\mu_{i}
$$

This expression measures the number of appearance of $y_{i}=1$ for each given independent variable.

The entrepreneurial intention is modeling in table 2.

\begin{tabular}{|c|c|c|c|}
\hline Variables & & \multicolumn{2}{|l|}{ Indicators } \\
\hline \multicolumn{2}{|c|}{ 1. Dependent variable $(Y)$} & Numbers & modalities \\
\hline Entrepreneur & Be an entrepreneur or no & 2 & $\mathrm{Yes}=1, \mathrm{No}_{\mathrm{o}}=0$ \\
\hline \multicolumn{4}{|c|}{ 2. Independents Variables $(X)$} \\
\hline 2.1 Home country & Student home country & 5 & $\begin{array}{l}\text { North, West Center East } \\
\text { and Southern Africa }\end{array}$ \\
\hline 2.2.Gender & Student gender & 2 & Male and Female \\
\hline 2.3. Age & Age of student & \multicolumn{2}{|c|}{ Quantitative variable } \\
\hline 2.4.Study Level & Student background of study & 4 & $\begin{array}{l}\text { Bachelor, Master, } \\
\text { Doctorate and Other } \\
\text { level }\end{array}$ \\
\hline 2.5. Fields of study & Student major & 4 & $\begin{array}{l}\text { Medicine, Engineering } \\
\text { Economics and Other } \\
\text { major }\end{array}$ \\
\hline 2.6. City & Student location in China & 2 & $\begin{array}{l}\text { North and South of } \\
\text { China }\end{array}$ \\
\hline
\end{tabular}

Table 2. Entrepreneurial intention model: variables and indicators

Source: Authors' survey 


\section{Findings and interpretations of the study}

\subsection{Logistic regression results}

Tables below presented the results of logistic regression (first and second estimations, odds ratio, and marginal effects). Each variable was codified. Variables countries are respectively: West Africa (country 2), Central Africa ( country 3), East Africa (country 4) and Southern Africa (country 5); variable gender (gender); variable age (age; )variables of study level are: master (level 2), doctorate (level 3) and other level (level 4); variables of fields of study are: engineering ( Major 2), economics (major 3) and other majors (major 4) and variable city is South of China (city 2). In this study, the variable other major included all the fields of study such as geography, history, Chinese language, and other that were less represented among respondents as well as other level that included, other post-graduates programs and other professional training.

Table 3. First estimation of logistic estimation:

\begin{tabular}{|c|c|c|c|c|}
\hline $\begin{array}{l}\text { xi : logit } \\
\text { i. COUNTRY } \\
\text { i. ALEVEL } \\
\text { i. MAJOR } \\
\text { i. CITY }\end{array}$ & NT & $\begin{array}{l}\text { i.COUNTRY GE } \\
\text {-ICOUNTRY_1-5 } \\
\text {-IALEVEL_1-4 } \\
\text {-IMAJOR_1-4 } \\
\text { _ICITY_1-2 }\end{array}$ & & $\begin{array}{l}\text { AGE } i \\
\text { (nat } \\
\text { (nat } \\
\text { (nat } \\
\text { (nat }\end{array}$ \\
\hline $\begin{array}{l}\text { teration } 0: \\
\text { teration } 1: \\
\text { teration } 2: \\
\text { teration } 3: \\
\text { teration } 4:\end{array}$ & $\begin{array}{l}\log \\
\log \\
\log \\
\log \\
\log \end{array}$ & $\begin{array}{l}\text { likelihood } \\
\text { likelihood } \\
\text { likelihood } \\
\text { likelihood } \\
\text { likelihood }\end{array}$ & $\begin{array}{l}-7 \\
-7\end{array}$ & 1 \\
\hline
\end{tabular}

Logistic regression

$\begin{array}{llr}\text { Number of obs } & = & 141 \\ \text { LR chi2(13) } & = & 28.64 \\ \text { Prob > chi2 } & = & 0.0074 \\ \text { Pseudo R2 } & = & 0.1608\end{array}$

Log 1ike1ihood $=-74.718642$

AGE i.ALEVEL i.MAJOR i.CITY

(natural1y coded; _ICOUNTRY_1 omitted)

(natural1y coded; _IALEVEL_1 omitted)

(naturally coded; _IMAJOR_1 omitted)

natura11y coded; _ICITY_-1 omitted)

\begin{tabular}{r|rrrrrr}
\hline ENT & Coef. & Std. Err. & $z$ & $\mathrm{P}>|\mathrm{z}|$ & [95\% Conf. Interva1] \\
\hline -ICOUNTRY_2 & 2.726192 & 1.268924 & 2.15 & 0.032 & .2391453 & 5.213238 \\
-ICOUNTRY_3 & 2.226226 & 1.285693 & 1.73 & 0.083 & -.2936865 & 4.746138 \\
-ICOUNTRY44 & 2.768655 & 1.314495 & 2.11 & 0.035 & .192292 & 5.345018 \\
-ICOUNTRY_5 & 1.205982 & 1.286175 & 0.94 & 0.348 & -1.314873 & 3.726838 \\
GENDER & .9753323 & .492704 & 1.98 & 0.048 & .0096502 & 1.941014 \\
AGE & .0664611 & .0548958 & 1.21 & 0.226 & -.0411326 & .1740549 \\
-IALEVEL_2 & -.5804514 & .5606216 & -1.04 & 0.300 & -1.67925 & .5183468 \\
-IALEVEL_3 & -1.262598 & 1.004769 & -1.26 & 0.209 & -3.231909 & .7067133 \\
-IALEVEL_4 & .5718584 & 1.011777 & 0.57 & 0.572 & -1.411188 & 2.554904 \\
-IMAJOR_2 & .0083532 & .5229002 & 0.02 & 0.987 & -1.016512 & 1.033219 \\
-IMAJOR_3 & 1.358439 & .8825049 & 1.54 & 0.124 & -.3712384 & 3.088117 \\
-IMAJOR_4 & 1.29696 & .5530189 & 2.35 & 0.019 & .2130625 & 2.380857 \\
-ICITY_2 & .7385089 & .6298221 & 1.17 & 0.241 & -.4959198 & 1.972938 \\
-COnS & -4.014354 & 1.83595 & -2.19 & 0.029 & -7.612749 & -.4159582
\end{tabular}

Notes: given the fact that the logistic regression output tables are used, the levels of significance cannot be marked in the table. Prob $>$ Chi2 denotes the statistical significance at 1 percent while $p>|z|(\mathrm{P}$-value $<0,1)$ indicates the statistical significance at 10 percent level.

The results reported in table 3 above; revealed that the model was statistically valid: the Chi-Two was significant at 1 percent level, P-Value $=0.0074$. This means, the explanatory variables $(X)$ have an effect on dependent variable $(Y)$. However, when taking each variable, only variables (country, gender and major) were significant at 10 percent; P-value $<0,1$ (See $p>|z|$ in table 3 ), so the variables (age, study level and city) that were not significant were removed and the model was tested again (see table 4). 
Table 4. Second estimation of logistic estimation

\begin{tabular}{|c|c|c|c|c|c|c|c|}
\hline $\begin{array}{l}\text { xi : logit } \\
\text { i.COUNTRY } \\
\text { i.MAJOR }\end{array}$ & \multicolumn{2}{|c|}{$\begin{array}{l}\text { i. COUNTRY GENDER } \\
\text {-ICOUNTRY_1-5 } \\
\text {-IMAJOR_1-4 }\end{array}$} & \multicolumn{2}{|c|}{$\begin{array}{l}\text { i.MAJOR } \\
\text { (natura11y coded; } \\
\text { (natura11y coded; }\end{array}$} & \multicolumn{3}{|c|}{$\begin{array}{l}\text { ICOUNTRY_1 omitted) } \\
\text { _IMAJOR_1 omitted) }\end{array}$} \\
\hline $\begin{array}{l}\text { Iteration } 0: \\
\text { Iteration } 1: \\
\text { Iteration } 2: \\
\text { Iteration } 3: \\
\text { Iteration } 4:\end{array}$ & $\begin{array}{l}\text { log 1ikelih } \\
\text { log 1jkelih } \\
\text { log 1ikelih } \\
\text { log 1ikelih } \\
\text { log 1ikelih }\end{array}$ & $\begin{array}{l}d=-93.2 \\
d=-81.7 \\
d=-81.4 \\
d=-81.4 \\
d=-81.4\end{array}$ & $\begin{array}{l}2749 \\
7329 \\
2021 \\
1222 \\
1222\end{array}$ & \multirow{2}{*}{\multicolumn{2}{|c|}{$\begin{array}{l}\text { Number of obs } \\
\text { LR chi2( } 8) \\
\text { Prob > Chi2 } \\
\text { Pseudo R2 }\end{array}$}} & \multirow[b]{2}{*}{$\begin{array}{l}= \\
= \\
= \\
=\end{array}$} & \multirow[b]{2}{*}{$\begin{array}{r}148 \\
23.60 \\
0.0027 \\
0.1266\end{array}$} \\
\hline \multicolumn{4}{|c|}{ Logistic regression } & & & & \\
\hline ENT & Coef. & Std. Err. & $\mathbf{z}$ & $P>|z|$ & {$[95 \%$} & Conf. & Interva1] \\
\hline $\begin{array}{r}\text { _ICOUNTRY_2 } \\
\text { _ICOUNTRY_3 } \\
\text {-ICOUNTRY_4 } \\
\text { _ICOUNTRY_5 } \\
\text { _ICOUNDER } \\
\text { GENDE } \\
\text {-IMAJOR_2 } \\
\text {-IMAJOR_3 } \\
\text {-IMAJOR_4 } \\
\text {-COnS }\end{array}$ & $\begin{array}{r}1.944198 \\
1.892377 \\
2.15508 \\
.6188923 \\
.7263161 \\
.2363779 \\
1.716228 \\
1.144704 \\
-1.82252\end{array}$ & $\begin{array}{l}1.041546 \\
1.072411 \\
1.089973 \\
1.082974 \\
.4015884 \\
.5009147 \\
.8518678 \\
.4960037 \\
1.065208\end{array}$ & $\begin{array}{r}1.87 \\
1.76 \\
1.98 \\
0.57 \\
1.81 \\
0.47 \\
2.01 \\
2.31 \\
-1.71\end{array}$ & $\begin{array}{l}0.062 \\
0.078 \\
0.048 \\
0.568 \\
0.071 \\
0.637 \\
0.044 \\
0.021 \\
0.087\end{array}$ & $\begin{array}{r}-.09719 \\
-.20951 \\
.01877 \\
-1.5036 \\
-.06078 \\
-.74539 \\
.0465 \\
.17255 \\
-3.910\end{array}$ & $\begin{array}{l}942 \\
105 \\
731 \\
698 \\
828 \\
969 \\
598 \\
549 \\
029\end{array}$ & $\begin{array}{l}3.985591 \\
3.994265 \\
4.291388 \\
2.741482 \\
1.513415 \\
1.218153 \\
3.385858 \\
2.116854 \\
.2652505\end{array}$ \\
\hline
\end{tabular}

Notes: given the fact that the logistic regression output tables are used, the levels of significance cannot be marked in the table. Prob $>$ Chi2 denotes the statistical significance at 1 percent while $p>|z|(\mathrm{P}$-value $<0,1)$ indicates the statistical significance at 10 percent level.

This second estimation showed that the model was statistically valid: the Chi-Two was significant at 1 percent $(\mathrm{P}-$ Value $=0.0027)$. Each single variable (country, gender and major) were significant at 10 per cent level (P-value $<0,1)$. Variables country of origin and major (fields of study) has a positive influence on students' intention to become an entrepreneur.

For more interpretation of first and second estimation results odds ratios and marginal effects were used (table 5 and table 6).

Table 5. Odds ratio results

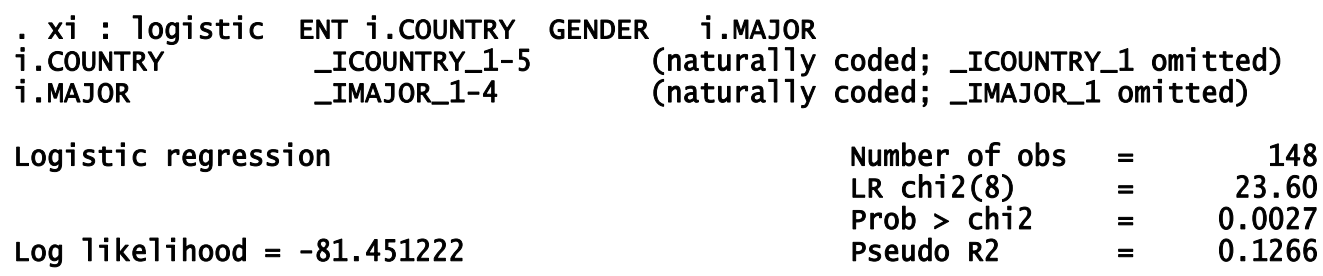

\begin{tabular}{r|rrrrrr}
\hline ENT & Odds Ratio & std. Err. & $z$ & $\mathrm{P}>|\mathbf{z}|$ & [95\% Conf. & Interva1] \\
\hline _ICOUNTRY_2 & 6.988028 & 7.278352 & 1.87 & 0.062 & .9073798 & 53.81709 \\
-ICOUNTRY_3 & 6.635122 & 7.11558 & 1.76 & 0.078 & .8109811 & 54.2859 \\
-ICOUNTRY4 & 8.628583 & 9.40492 & 1.98 & 0.048 & 1.01895 & 73.06778 \\
_ICOUNTRY55 & 1.85687 & 2.010942 & 0.57 & 0.568 & .2223066 & 15.50996 \\
GENDER & 2.06745 & .8302641 & 1.81 & 0.071 & .9410277 & 4.542216 \\
-IMAJOR_2 & 1.266653 & .6344851 & 0.47 & 0.637 & .4745459 & 3.380936 \\
-IMAJOR_3 & 5.563504 & 4.73937 & 2.01 & 0.044 & 1.047701 & 29.54334 \\
-IMAJOR_4 & 3.141512 & 1.558202 & 2.31 & 0.021 & 1.188337 & 8.304966 \\
\hline
\end{tabular}

Notes: given the fact that the logistic regression output tables are used, the levels of significance cannot be marked in the table. Prob $>\mathrm{Chi} 2$ denotes the statistical significance at 1percent while $p>|z|(\mathrm{P}$-value $<0,1)$ indicates the statistical significance at 10 percent level. 
According to odds ratio results, a probability of being an entrepreneur is 6.98 times higher among students who come from West Africa, it is 6.63 higher from students who come from Central Africa, and this probability is 8.62 higher from students who come from East Africa Students of North Africa were used as base category. Concerning gender distribution, male African students are 2 times more likely to be entrepreneurs than female African students (base category). Results on fields of study revealed; students' majoring in engineering are 1.26 times more willing to pursue entrepreneur career than medicine students African students specializing in economics are 5.56 times more willing to be entrepreneurs than students specialized in medicine (medicines students were used as base category).

Table 6. Marginal effect estimation

. mfx compute

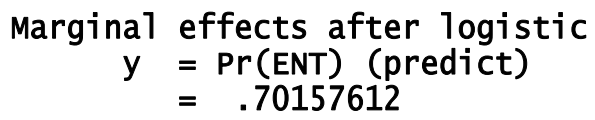

\begin{tabular}{|c|c|c|c|c|c|c|c|}
\hline variable & $d y / d x$ & Std. Err. & $z$ & $P>|z|$ & $95 \%$ & C.I. & $x$ \\
\hline _ICOUN 2* & .3435788 & .15082 & 2.28 & 0.023 & .047971 & .639187 & .331081 \\
\hline ICOUN 3* & 2421 & 1338 & 2.34 & 0.020 & .050182 & 57466 & .25 \\
\hline ICOUN 4* & .3286347 & .11423 & 2.88 & 0.004 & .104754 & .552516 & .209459 \\
\hline ICOUN $5^{*}$ & .1182421 & .18606 & 0.64 & 0.525 & -.246429 & .482913 & .175676 \\
\hline GENDER* & .1551878 & .08641 & 1.80 & 0.073 & -.014174 & .32455 & .594595 \\
\hline _IMAJO 2* & .0481655 & .09929 & 0.49 & 0.628 & -.146443 & .242774 & .22973 \\
\hline _IMAJO $3^{*}$ & .2526726 & .07729 & 3.27 & 0.001 & . 101194 & . 404151 & 101351 \\
\hline IMAJO 4* & .2142707 & .08107 & 2 & 0.008 & .055376 & .373166 & .297297 \\
\hline
\end{tabular}

(*) $d y / d x$ is for discrete change of dummy variable from 0 to 1

According to marginal effect estimation, the probability of being an entrepreneur increases by 34.35 per cent from students of West Africa; it increases by 31.24 per cent from students of Central Africa, and this probability is 32.86 per cent from students of East Africa while the result was not significant for students from Southern Africa. Result for gender variable revealed: the probability of being an entrepreneur increases by 15.51 per cent among male students compared to female students. Concerning student fields of study; the probability to be entrepreneur increases by 25.26 per cent among students majoring in economics and 4.80 per cent for engineering sciences.

Broadly, results from the model suggest a positive influence of three main variables (home country, gender and fields of study)as determinants factors to entrepreneurial intention. Social and individual characteristics determined African students' perception towards entrepreneurship. Social characteristic is defined from student home country that was significant than students' city location in China. In terms of importance of marginal effects, country of origin from West Africa, East Africa and Central Africa have most important effect at a level of 10 per cent. This result is similar to the findings of Black and Castaldo, (2009) studying return migrants in Ghana and Cote d'Ivoire found that country of origin has a significant effect on return migrants' intention to start a new business. Individual characteristics were significant on two variables, student fields of study (major) and gender. Students fields of studies was significant than the level of study. Fields of study has a significant effect on the decision to be entrepreneurs and student majoring in economics are significantly more likely to be entrepreneurs at a level of 10 per cent. These findings are similar with Tounes (2006) and Boissin et al. (2008) analyzing students' intention towards entrepreneurship found that training programme on entrepreneurship has a positive effect on students' perception towards entrepreneurship. Gender of students was significant to intention towards entrepreneurship; men were significantly more willing to be entrepreneurs than women while the age was not significant. Analysis from the model stressed the influence of individual personal characteristics and social characteristics as positive factors that could motivate students to undertake entrepreneurial activities.

\subsection{Descriptive statistic results}

5.2.1 Entrepreneurial intention is measured from students' choice of professional career

To the question: After your return would you like to be an employee or an entrepreneur?, the results revealed that 54.1 per cent of the respondents wanted to be entrepreneurs, while 32.4 per cent wanted to be employees and 13.5 per cent wanted to be both (employees and entrepreneurs). The following analyses are based on 67.6 per cent of students who wanted to be entrepreneurs and those who wanted to be both employees and entrepreneurs. 


\subsubsection{Attitudes}

Based on the question why do you choose to be an entrepreneur?, findings revealed that African students' choice to be an entrepreneur (to create enterprise) depended on beliefs based on what they think; being entrepreneurs could satisfy their expectation (to create their own jobs) as answered by 67.7 per cent, to have power, as claimed by 44.4 per cent, to take risks $(64.6 \%)$ and to implement creativity (87.9\%). This result is similar to Boissin et al. (2008) who found that French students career choice was based on the beliefs they have towards a given career choice (entrepreneur or employee).

\subsubsection{Student capability Perceived}

A yes or no question was asked for students to agree or disagree on each variable of capability perceived (professionals skills, academic background, enterprise spirit, investment project and personal savings) that could allow them to undertake entrepreneurial activities. The various answers of this question indicated that 67.6 per cent of African students wanted to be entrepreneurs and were confidents on their professional skills were 68.7 per cent of the respondents. Academic background was represented by 65.7 per cent, enterprise spirit by 88.9 per cent, investment project by 56.7 per cent and personal savings by 68.7 per cent. These findings revealed that enterprise spirit, professional skills and personal savings are major factors that will allow the African students to start entrepreneurial activities when they return to Africa. These results are in line with Bandura (1997) who argued that individual self-efficacy is a determinant factor to perform the behavior.

Table 7 below summarize variable from students capability perceived. Only the percentage of yes was reported in the table.

Table 7. Student's capacity perceived

\begin{tabular}{lccll}
\hline Items & Items & Frequencies & Percentage (\%) & $\begin{array}{l}\text { Effect on Creation } \\
(\%)\end{array}$ \\
\hline professional skills & Yes & 68 & 68.7 & 68.7 \\
$\begin{array}{l}\text { academic background } \\
\text { enterprise spirit }\end{array}$ & Yes & 65 & 65.7 & 65.7 \\
& Yes & 88 & 88.9 & 88.9 \\
$\begin{array}{l}\text { investment project ready } \\
\text { implement } \\
\text { personal saving }\end{array}$ & Yes & 56 & 56.6 & 56.6 \\
& Yes & 68 & & 68.7
\end{tabular}

Source: Authors' survey

\subsubsection{Environment context}

In our previous model we showed that environment context is evaluated from the country of origin and location in a Chinese city. Logistic regression demonstrates that students' country influences students' entrepreneurial intention. Descriptive statistics confirms the fact that institutional environment are determinant factors to enterprise creation (North, 1990, Scott, 2001 and Chow, 2004). Based on this question of what are the factors that may motivate you to set up a company in your country? The results revealed that the improved economic environment in students home country (business opportunity was quoted by $79.8 \%$; rules and regulation for entrepreneurship promotion by $71.7 \%$ ). China's economic environment was also a motivating factor to enterprise creation; Knowledge of Chinese market, as affirmed by 57.6 per cent and business opportunity with Chinese investors, as claimed by 57.6 per cent of the respondents. Numbers of positives answers (yes) on each variable from environment context are summarized in table 8. 
Table 8. Environment context

\begin{tabular}{lllll}
\hline Items & Items & Frequencies & Percentage $(\%)$ & $\begin{array}{l}\text { Effect on creation } \\
(\%)\end{array}$
\end{tabular}

\section{China(city)}

$\begin{array}{lcccc}\text { Knowledge of Chinese market } & \text { Yes } & 57 & 57.6 & 57.6 \\ \text { Opportunity of partnership with } & \text { Yes } & 57 & 57.6 & 57.6\end{array}$

Chinese investors

\section{Home Country}

Rules \& regulations promoting entrepreneurship Yes $\quad 71$

71.7

71.7

Subsidies to young entrepreneurs

Yes

by government

Business opportunity from my Yes

country

Family financial support

Yes

Bank loans from home

Yes

Opportunity of partnership with Yes

home investors

Source: Authors' survey

\section{Discussion and Conclusion}

The above results give some determinants factors to entrepreneurial intention among African students living and studying in China. The entrepreneurial intention model assumed the behavior of African students is influenced by the attitudes, subjective norms and perceived behavior.

\subsection{Attitudes}

The Attitudes is analyzed from students' background (age, gender, study level and fields of study) but only variables such as fields of study and gender were significant at 10 percent (P-value $<0,1)$. Globally, students background influence positively their entrepreneurial intention, these results verified Hypothesis 1 confirming that African students' attitudes are determinant factors that influence positively their entrepreneurial intention. According to gender variables the result are more similar to the previous study on impact of gender on entrepreneurial intention (Zhao et al., 2005) that men are more willing to be entrepreneurs than women (African students male were 2 times more likely to be entrepreneurs than African female students). As previous researchers have found, individual background indirectly influences human behavior (Ajzen, 1991) and (Liñán, 2005). In the contrary, students' positive beliefs have the positive influence on entrepreneurial intention; descriptive statistics revealed that most of students chose to be an entrepreneur because they want to implement their creativity as said by 87.9 per cent of the research subjects or to create their own jobs as declared by 67.7 per cent of the research participants. The variable implement creativity that have a high percentage, could be explained from the fact that entrepreneurial spirit is high among African students majoring in economics (5.56 times more willing to be an entrepreneur) because their studies programme contains economic notions; so they are more familiar to production and enterprise creation notions than students from medicine or others majors, and they are mostly willing to create enterprises. These results confirm the importance of training programme on entrepreneurship supported by other researchers such as Boissin et al. (2008), Liñán (2005).

\subsection{Social norms}

The social norms are analyzed from environment context (city location in China and home country). Intention model revealed that students' location in China does not have an effect on entrepreneurial intention. Country of origin is the 
determinant factor to entrepreneurial intention. This fact verified Hypothesis 2 stipulating that African students' institutional environment are determinant factors of entrepreneurial intention. Students' home country of origin is the determinant factor to entrepreneurial activities. The results proved that students from West Africa are more willing to be entrepreneurs (34.35\%), followed by students from East Africa (32.86 \%) and students from Central Africa $(31.24 \%)$. Descriptive statistics revealed that students considered economic factors such as: business opportunity, rules and regulations for entrepreneurship promotion, subsidies to the youths, bank loans and opportunity of partnership with home investors as determinant factors to enterprise creation. These results are in line with scholars' views (Kostova, 1997, Casson, 1990 and Acemoglu et al., 2003) as early noticed that institutional environment positively influence the development of entrepreneurship and country local environment determined the level and the difference in entrepreneurship development across countries. These results also call upon African governments to set a suitable economic environment that could allow African students from abroad to activate their entrepreneurial creativity.

\subsection{Perceived behavior control}

A perceived behavior control is measured from personal factors: African students believe their enterprise spirit, professional skills, academic background, investment projects and personal savings are determinant factors to create enterprise. These results explain the fact that students from the economics domain are more willing to be entrepreneurs because they think; their academic training will allow them to be successful in entrepreneurial activities and it confirms hypothesis 3 arguing that African students' capability perceived (personal factors) influences positively their entrepreneurial intention. These results revealed the necessity of orientation to African students coming to study in China in the fields of economics and engineering to develop their enterprise spirit. This result is similar to the findings of Tounes (2006) who found that training programme on entrepreneurship stimulates students' entrepreneurial intention.

The purpose of this study was to find out the determinant factors to entrepreneurial intention among African students living and studying in China. The study involved students approaching their graduation and had to tell what professional career they will choose by the time they return to Africa. The theory of planned behavior was used to analyze African students' determinant factors to entrepreneurial intention. Intention model was drawn with some specificity (the model used students' background as measurement of attitudes, environment context, as a measurement of social norms and personal factor, as measurement of perceived behavior control). The model was tested from logistic regression and the descriptive statistics results were used for empirical analysis. The findings revealed that African students' gender, fields of study, home country economic environment and personal factors (capability) are main determinants factors that have a positive influence on entrepreneurial intention.

\section{Limitations and Directions for Future Research}

This study revealed the importance of African students training in fields of economic sciences and engineering sciences, Africa needs more engineers, technicians and entrepreneurs with high skills; the Chinese education system offers these opportunities to African students across many Chinese universities. The improvement of African business climate is a requirement to promote enterprise creation as well as economic reforms such as those that made China to achieve high economic growth. Africa governments need to create a suitable economic environment that will allow African students from abroad to return and establish business ventures that would provide employment opportunities.

However, this paper has three major limitations. First, the sample of the study that is not certainly representative of the population of African students who are studying and living in China and the analysis just focused on students' perception towards entrepreneurship not whether that they have already started some businesses activities and contributing to their home country economic development. Further research can deepen study African students who owned some entrepreneurial activities when they are still pursuing studies abroad. Second, study mainly focused on student beliefs to predict their entrepreneurial intention, it is not absolute that all African students in China will fulfill their intention. Some of these students' entrepreneurial intention may change after their return, or may find various barriers to realize their intentions. Research in future on the sample of students will find out how students with high positive intention towards enterprise creation can be able to create their own enterprise. Future research could also study the entrepreneurial activities of the returnee graduates to Africa. Third, the study used environment context as social norms rather than social groups (parents, friends, community) usually used in most studies on individual entrepreneurial intention. Future research could find out the influence of social groups on individual entrepreneurial intention in Africa context. 
Despite these limitations, the pertinence of the study still remains; it's found how institutional environment in general and economic environment and education in particularly are key determinants of entrepreneurial intention.

\section{References}

Acemoglu, D., Johnson, S., Robinson, \& Thaicharoen, Y. (2003). Institutional causes macroeconomics symptoms: volatility, crises and growth. Journal of Monetary economics, 50(1), 49-123. http://dx.doi.org/10.1016/S0304-3932(02)00208-8

Ajzen, I. (2008). Consumer attitudes and behavior. Handbooks of Consumer Psychology 525-548.

Ajzen, I. (1991). Theory of Planned Behavior. Organizational behavior and human decision processes 50(2): 179-211. http://dx.doi.org/10.1016/0749-5978(91)90020-T

Ajzen, I. \& Fishbein, M. (2000). Attitude and Attitude Behavior Relation: Reasoned and automatic processes. European Review of Social Psychology 11(1): 1-33. http://dx.doi.org/10.1080/14792779943000116

Bandura, A. (1997). Self-efficacy: The exercise of control. MacMillan.

Black, R \& Castaldo, A. (2009). Return migration and entrepreneurship in Ghana and Cote d'Ivoire: The role of capital transfers. Tjjdschriff voor economishe en sociale geografie 100 (1), 44-58. http://dx.doi.org/10.1111/j.1467-9663.2009.00504.x

Boissin, J P., Chollet, B., \& Emin, S. (2008). Les croyances des étudiants envers la création d'entreprise.(Students beliefs towards enterprise ceration) Revue Française de Gestion 11: 25-43. http://dx.doi.org/10.3166/rfg.180.25-43

Bruton G.D, Ahstrom D, \& Obloj, K. (2008). Entrepreneurship in emerging economics where are we today and where should the research go in the future. Entrepreneurship Theory and Pratrice. 32(1), 1-14. http://dx.doi.org/10.1111/j.1540-6520.2007.00213.x

Bygrave, W.D. \& Hofer, C. W. (1991). Theorizing about Entrepreneurship. Entrepreneurship Theory and Practice 16(2):13-22.

Campbell, J.L. (2004). Institutional Change and Globalization. Princeton University Press.

Casson, M. (1990). Enterprise and competitiveness. New York; Oxford University Press.

Chow, G.C. (2004). Economic reform and growth in China. ANNALS OF ECONOMICS AND FINANCE 5: 93-118.

De Clercq, D., Danis, W. M., \& Dakhili, M. (2010). The moderating effect of institutional context on the relationship between associational activity and new business activity inemerging economies. International Business Review, 19, 85-101. http://dx.doi.org/10.1016/i.ibuserev.2009.09.002

Djankov, S., Qian, Y., Roland, G \& Zhuravskaya, E.(2006). Entrepreneurship in development: First Results from China and Russia. Paper presented at the American Economic Association Conference. Boston, MA.

Drucker, P. (1985). Les Entrepreneurs (The entrepreneurs). Editions Tendances Actuelles: L'Expansion Hachette, Jean Claude Lattes.

Eesley, C.E (2009). Entrepreneurship and China: History of policy reforms and institutional development. Retrieved from http://web.stanford.edu/ cee/Papers/Entrepreneurship\%20and\%20China-7-10-09.pdf

Gupta,V.K., Guo, C., Canever, M., Yim, H. R., Sraw, G. K., \& Liu, M. (2014). Institutional Environment for entrepreneurship in rapidly emerging major economies: the case of Brazil, China, India and Korea. International Entrepreneurship and Management Journal, 10(2), 367-384. http://dx.doi.org/10.1007/S11365-012-0221-8

Hosmer, D. W., Lemeshow, S \& Sturdivant, R X. (2000). Introduction to the logistic regression model. (pp1-33). John Wiley \& Sons, Inc.

Kolvereid, L. (1996a). Organizational employment versus self-employment: Reasons for career choice employment. Entrepreneurship Theory and Patrice 20(3): 23-32.

Kostova, T. (1997). Country institutional profiles: Concept and measurement. Academy of Management Best Paper Proceeding: 180-189.

Kurland, N. B. (1996). Sales agents and clients: ethics, incentives, and a modified theory of planned behavior. Human Relations 49(1): 51-74. http://dx.doi.org/10117/001872679604900103 
Li, H., Meng, L \& Zhang, J. (2006). Why do entrepreneurs enter politics: Evidence from China. Economic Inquiry 44 (3): 559-578. http://dx.doi.org/10.1093/ei/cbj031

Liñán, F. (2004). Intention based model of entrepreneurial education. Piccolla Impresa/Small Business 3(1):11-35.

Liu, Y. (2002). Development of private entrepreneurship in China: Process, Problems and Countermeasures. Chinese Academy of Social Sciences (CASS). Working Paper. http://www.mansfieldfdn.org/backup/programs/program_pdfs/ent_china.pdf. (Accessed July 31, 2014).

Mc Clellan, D. C. (1961). The achieving society. London: The Free Press.

Nguyen, M .N, Potvin, L \& Otis, J. (1997). Regular exercise in 30-to 60-year old men: Combining the stages of change model and the theory of planned behavior to identify determinants for targeting heart health interventions. Journal of Community Health 22(4): 233-246. http://dx.doi.org/10.1023/A:1025196218566

North, D. (1990). Institutions, Institutional Change and Economic Performance. Cambridge, Cambridge University Press. http://dx.doi.org/10.1017/CBO9780511808678

Robinson, P. B., Stimpson,D., Huefner, J. C., \& Hunt, H. K. (1991). An attitude approach to the prediction of entrepreneurship. Entrepreneurship Theory and Pratrice, 15(4): 13-31.

Ronstadt, R.C. 1984. Entrepreneurship. Dover. MA: Lord Publishing.

Scott, W.R. (2001). Institutions and Organizations. Thousand Oaks, Sage Publications.

Shane, S \& Venkataraman, S. (2000). The promise of entrepreneurship as a field of research. Academic of Management Review (25)1: 217-226. http://dx.doi.org/10.5465/AMR.2000.2791611

Shapero, A \& Sokol, L. (1982). The social dimension of entrepreneurship. Kent C.A., Sexton D.L\& Vesper K.H. (Eds.).The Encyclopedia of entrepreneurship, Englewood Cliffs NJ, Prentice. Hall 72-90.

Schifter, D.E \& Ajizen, I. (1985). Intentions, perceived control and weight loss: An application of theory of plan behavior. Journal of Personality and Social Psychology 49: 843-851. http://dx.doi.org/10.1037/0022-3514.49.3.843

Schumpeter, J. A. (1939). Business Cycle. New York: Mc Graw-Hill.

Stevenson, H.H \& Jarillo, J.C. (1990). A paradigm of entrepreneurship: Entrepreneurial Management. Strategic Management Journal 11(5): 17-27.

Tounes, A. (2006). L'intention entrepreneuriale des étudiants: le cas français (Students entrepreneurials' intention : French case). La Revue des Sciences de Gestion 3: 57-65.

Verstraete, T. (2003). Proposition d'un cadre théorique pour la recherche en entrepreneuriat (A proposition of theoretical framework for entrepreneurship research). Editions de l'ADREG, on http;//www.airepme.org/images/File/Livres/adreg 07.pdf (accessed April 14, 2014).

Wei, L. (2012). On treating intercultural communication anxiety of international students in China. World Journal of Education 2(1): 55-61.

Williamson.O.E. (2000). The new institutional economics; taking stock, looking ahead. Journal of economic literature, 565-613.

Zhao, H., Seibert, S. E \& Hills, G.E. (2005). The mediating role of self-efficacy in the development of entrepreneurial intentions. Journal of Applied Psychology 90 (6): 1265-1272. http://dx.doi.org/10.1037/0021-9010.90.6.1265

\section{Notes}

Note 1. This passage was inspired by the work of Mbikyo, M.D. (2013). Comparative education. Kigali Institute of Education (KIE), Unpublished Module notes, Kigali, Uganda.

Note 2. This figure was adapted from Ajzen (1991) and Boissin et al. (2008). 